\title{
Penerapan Model Pembelajaran Inkuiri Terbimbing untuk Meningkatkan Keterampilan Berpikir Kritis Peserta Didik SMP
}

\author{
Magfirah Maulani $^{1)} *$ Hunaidah $^{2)}$, Erniwati $^{3)}$ \\ 1)* Mahasiswa Pendidikan Fisika Fakultas Keguruan dan Ilmu Pendidikan Universitas Halu Oleo \\ ${ }^{2), 3)}$ Dosen Pendidikan Fisika Fakultas Keguruan dan Ilmu Pendidikan Universitas Halu Oleo
}

*Korespondensi Email: magfirah@gmail.com

\begin{abstract}
Abstrak: Penelitian ini bertujuan untuk mengetahui peningkatan keterampilan berpikir kritis peserta didik kelas VIII $_{\mathrm{E}}$ SMP Negeri 4 Buton Tengah yang diajar dengan menggunakan model pembelajaran inkuiri terbimbing pada materi cahaya dan alat optik. Jenis penelitian ini adalah PTK yang telah dilaksanakan dalam dua siklus. Subjek penelitian ini adalah seluruh peserta didik yang berjumlah 22 orang siswa, terdiri dari 13 laki-laki dan 9 perempuan yang terdaftar pada semester genap tahun ajaran 2018/2019. Teknik pengumpulan data dilakukan dengan observasi untuk mengetahui aktivitas guru dan tes essay dilakukan untuk mengetahui keterampilan berpikir kritis peserta didik. Teknik analisis data menggunakan statistik deskriptif. Hasil analisis data dan pembahasan diperoleh kesimpulan yakni keterampilan berpikir kritis peserta didik pada siklus I meningkat pada tiap indikatornya di siklus II, dengan nilai rata-rata keterampilan berpikir kritis pada siklus I sebesar 45,68 yang berada pada kategori rendah dan nilai rerata keterampilan berpikir kritis pada siklus II sebesar 70,23 yang berada pada kategori sedang.
\end{abstract}

Kata Kunci: Model pembelajaran inkuiri terbimbing; keterampilan berpikir kritis

Abstract: This study aims to determine the increase in critical thinking skills of class VIIIE students of SMP Negeri 4 Buton Tengah who are taught using guided inquiry learning models on light material and optical instruments. This type of research is the PTK which has been carried out in two cycles. The subjects of this study were all students, totaling 22 students, consisting of 13 boys and 9 girls who were registered in the even semester of the 2018/2019 academic year. Data collection techniques were carried out by observation to determine teacher activity and essay tests were conducted to determine students' critical thinking skills. The data analysis technique used descriptive statistics. The results of data analysis and discussion obtained the conclusion that the critical thinking skills of students in cycle I increased in each indicator in cycle II, with an average value of critical thinking skills in cycle I of 45.68 which is in the low category and the average value of critical thinking skills. in cycle II amounted to 70.23 which is in the medium category.

Keywords: Guided inquiry learning model; critical thinking skills.

\section{PENDAHULUAN}

Mata pelajaran fisika sebagai bagian dari Ilmu Pengetahuan Alam (IPA) merupakan ilmu-ilmu dasar yang perlu diajarkan kepada peserta didik. Keaktifan peserta didik dalam pembelajaran IPAFisika sangat penting, karena pembelajaran haruslah berpusat pada peserta didik, dan tidak hanya ditekankan pada hasil tetapi juga sangat ditekankan pada proses untuk mencapai hasil tersebut. Cahyono (2013) menyatakan bahwa keaktifan dalam belajar fisika terletak pada dua segi,yaitu aktif bertindak secara fisik (hands-on) dan aktif berpikir (minds-on). Secara umum keterampilan berpikir terdiri atas empat tingkatan,yaitu: menghafal (recall thinking), dasar (basic thinking), kritis (critical thinking) dan kreatif (creative thinking) (Krulik dan Rudnick, 1999).

Berdasarkan hasil wawancara dengan salah satu guru IPA di SMPN 4 Buton Tengah pada bulan November 2018, diperoleh info bahwa peserta didik di sekolah tersebut memiliki hasil belajar dan keterampilan yang dapat dikatakan belum optimal. Diungkapkan bahwa selama proses pembelajaran berlangsung, peserta didik tidak berani untuk bertanya dan mengungkapkan ide dan gagasannya. Selain itu, keterampilan peserta didik dalam 
menganalisis dan menyimpulkan suatu masalah juga dapat dikatakan masih kurang, peserta didik juga cenderung menginginkan rumus dan jawaban yang praktis ketika menjawab soal atau pertanyaan, sehingga menyebabkan kemampuan berpikir kritis peserta didik menjadi tidak terlatih. Kurangnya keterampilan berpikir kritis peserta didik kelas VIII dalam mengikuti pembelajaran ini menyebabkan peserta didik kurang memahami materi yang diajarkan oleh guru saat pembelajaran berlangsung, ini dibuktikan dengan nilai rata-ratahasil ulangan harian mata pelajaran IPA-Fisika semester genap tahun pelajaran2017/2018 pada materi pokok cahaya dan alat optik peserta didik kelas VIII menunjukkan bahwakelas $\mathrm{VIII}_{\mathrm{E}}$ mempunyai nilai paling rendah yakni dari 25 orang peserta didik hanya 7 orang peserta didik yang mampu mencapai KKM, sedangkan yang lain hanya mampu mencapai nilai rata-rata 42 dari KKM yang ditetapakan adalah 65 .

Masalah-masalah tersebut, diduga disebabkan oleh beberapa faktor yaitu (1) guru belum mampu menciptakan suasana belajar yang menarik untuk melatih keterampilan berpikir kritis peserta didik, (2) peserta didik kurang terlibat dalam proses pembelajaran,yang menjadikan peserta didik tidak terpacu untuk bertanya, mengungkapkan ide ataupun gagasannya, (3) peserta didik tidak pernah diarahkan untuk mencari tahu lebih dalam melalui proses eksperimen dan kurang memanfaatkan media pembelajaran (KIT) sebagai sumber belajar, sehingga dibutuhakan solusi dalam penyelesaian masalah tersebut.

Berdasarkan hal itu, peneliti bersama guru IPA memutuskan untuk menggunakan model pembelajaran inkuiri terbimbing yang dianggap mampu dan cocok untuk diterapkan. Model inkuiri terbimbing merupakan model pembelajaran yang mampu meningkatkan keterampilan berpikir kritis siswa (Noviana, 2017). Penggunaan model inkuiri terbimbing, siswa dapat memilih dan mengembangkan ide dan pemikirannya sehingga memperluas proses berpikir kritis yang berpusat pada keterampilan pemecahan masalah. Salah satu kegiatan yang dapat digunakan dalam pembelajaran IPA untuk memperoleh konsep dengan baik adalah dengan melakukan eksperimen.
Berdasarkan penelitaian yang telah dilakukan, Kurniawati dan kawan-kawan (2014) menemukan bahwa dengan inkuiri terbimbing, penguasaan konsep dan keterampilan berpikir kritis siswa menjadi lebih baik, Noviana dan kawan-kawan (2017) mengemukakan bahwa penerapan metode inkuiri terbimbing mampu meningkatkan aktivitas belajar, hasil belajar dan keterampilan berpikir kritis peserta didik. Berdasarkan uraian diatas, maka peneliti merasa perlu untuk melakukan penelitian serupa dengan materi dan subjek yang berbeda. Adapun judul dari penelitian yang akan dilaksanakan yaitu Penerapan Model Pembelajaran Inkuiri Terbimbing untuk Meningkatkan Keterampilan Berpikir Kritis Peserta Didik Kelas VIII $_{\mathrm{E}}$ SMP Negeri 4 Buton Tengah Pada Materi Cahaya dan Alat Optik.

\section{METODE}

Jenis penelitian ini adalah Penelitian Tindakan Kelas (PTK). PTK ini dilakukan dengan menerapkan model pembelajaran inkuiri terbimbing untuk meningkatkan keterampilan berpikir kritis peserta didik kelas VIII $_{\mathrm{E}}$ SMP Negeri 4 Buton Tengah pada materi pokok cahaya dan alat optik semester genap tahun ajaran 2018/2019. Penelitian ini dilaksanakan pada semester genap tahun ajaran 2018/2019, yang bertempat di kelas VIII $_{\mathrm{E}}$ SMP Negeri 4 Buton Tengah. Subjek penelitian ini adalah seluruh peserta didik kelas VIII $_{E}$ SMP Negeri 4 Buton Tengah yang berjumlah 22 orang siswa, terdiri dari 13 laki-laki dan 9 perempuan yang terdaftar pada semester genap tahun ajaran 2018/2019.

Data-data yang telah diperoleh dalam penelitian ini dianalisis dengan menggunakan statistik deskriptif untuk memberikan gambaran mengenai peningkatan keterampilan berpikir kritis dengan menggunakan instrumen tes esai sedangkan untuk keaktifan guru selama proses pembelajaran diperoleh dengan menggunakan lembar observasi selama proses pembelajaran berlangsung.

1. Aktivitas Guru

Analisis data lembar observasi aktivitas guru dalam kegiatan belajar mengajar, dirumuskan sebagai berikut.

$$
\text { Rata }- \text { rata }=\frac{\Sigma \text { SkorItem }}{\Sigma \text { Item }}
$$

(Arikunto, 2006)

Dengan:

$$
1=\text { Kurang; } 2 \text { = Cukup; } 3 \text { = Baik; } 4=\text { Sangat Baik }
$$


Klasifikasi rata-rata skor aktivitas guru dikategorikan seperti Tabel 1.

Tabel 1 Kategori Perolehan Aktivitas Guru

\begin{tabular}{cc}
\hline Interpretasi & Kategori \\
\hline $1 \leq$ rata rata $<1,75$ & Aktivitas kurang \\
\hline $1,75 \leq$ rata rata $<2,5$ & Aktivitas cukup \\
\hline $2,5 \leq$ rata rata $<3,25$ & Aktivitas baik \\
\hline $3,25 \leq$ rata rata $<4$ & Aktivitas sangat baik \\
\hline & (Sudjana,2005)
\end{tabular}

2. Analisis Peningkatan Keterampilan Berpikir Kritis mencari persentase skor. Menurut Suharsimi (2002), rumus yang digunakan yaitu.

Peningkatan keterampilan berpikir kritis dapat diketahui melalui tes uraian lalu dianalisis dengan

$$
P=\frac{S}{N} \times 100 \%
$$

Dengan:

$P=$ Persentase skor

$S=$ Jumlah skor yang diperoleh

$N=$ Jumlah skor maksimum

Nilai persentase keterampilan berpikir kritis yang diperoleh dari perhitungan, kemudian dikategorikan seperti pada Tabel 2.

Tabel 2. Kategori Perolehan Keterampilan Berpikir Kritis

\begin{tabular}{cc}
\hline Interpretasi (\%) & Kategori \\
\hline $81,25<\mathrm{X} \leq 100$ & Sangat tinggi \\
\hline $71,5<\mathrm{X} \leq 81,25$ & Tinggi \\
\hline $62,5<\mathrm{X} \leq 71,5$ & Sedang \\
\hline $43,75<\mathrm{X} \leq 62,5$ & Rendah \\
\hline $0<\mathrm{X} \leq 43,75$ & Sangat rendah \\
\hline
\end{tabular}

(Normaya dan Karim, 2015).

\section{HASIL PENELITIAN}

1. Siklus I

a. Analisis Data Keterampilan Berpikir Kritis

Data mengenai masing-masing indikator keterampilan berpikir kritis peserta didik kelas VIII $_{\mathrm{E}}$ SMP Negeri 4 Buton Tengahselama pembelajaran dengan menerapkan model inkuiri terbimbing pada materi cahaya dan alat optik diperoleh dengan menggunakan tes essay.

b. Deskripsi Keterlaksanaan Pembelajaran oleh Guru

Data keterlaksanaan pembelajaran oleh guru diperoleh dengan menggunakan lembar observasi aktivitas guru selama kegiatan belajar mengajar berlangsung.

c. Deskripsi Aktivitas Peserta Didik

Data mengenai aktivitas peserta didik selama proses belajar mengajar dengan menggunakan model inkuiri terbimbing pada materi pokok cahaya dan alat optik diperoleh menggunakan lembar obsevasi.

2. Siklus II

a. Analisis Data Keterampilan Berpikir Kritis
Data mengenai masing-masing indikator keterampilan berpikir kritis peserta didik kelas $\mathrm{VIII}_{\mathrm{E}}$ SMP Negeri 4 Buton Tengah selama pembelajaran dengan menerapkan model inkuiri terbimbing diperoleh dengan menggunakan tes esai. Deskripsi Keterlaksanaan Pembelajaran oleh Guru. Data keterlaksanaan pembelajaran oleh guru diperoleh dengan menggunakan lembar observasi aktivitas guru selama kegiatan belajar mengajar berlangsung. b. Deskripsi Aktivitas Peserta Didik

Data aktivitas peserta didik selama proses pembelajaran dengan menggunakan model inkuiri terbimbing materi pokok cahaya dan alat optik pada siklus II Grafik Hasil Kegiatan Pembelajaran

a. Grafik Nilai Rata-Rata Keterampilan Berpikir

Kritis Peserta Didik Setiap Siklus

Berdasarkan tabel sebelumnya diketahui bahwa terdapat peningkatan pada keterampilan berpikir kritis peserta didik kelas VIII $\mathrm{E}_{\mathrm{E}}$ SMP Negeri 4 Buton Tengah. Secara jelas perbandingan rata-rata nilai keterampilan berpikir kritis peserta didik kelas $\mathrm{VIII}_{\mathrm{E}}$ SMP Negeri 4 Buton Tengah pada siklus I dan Siklus II disajikan pada Gambar 1 


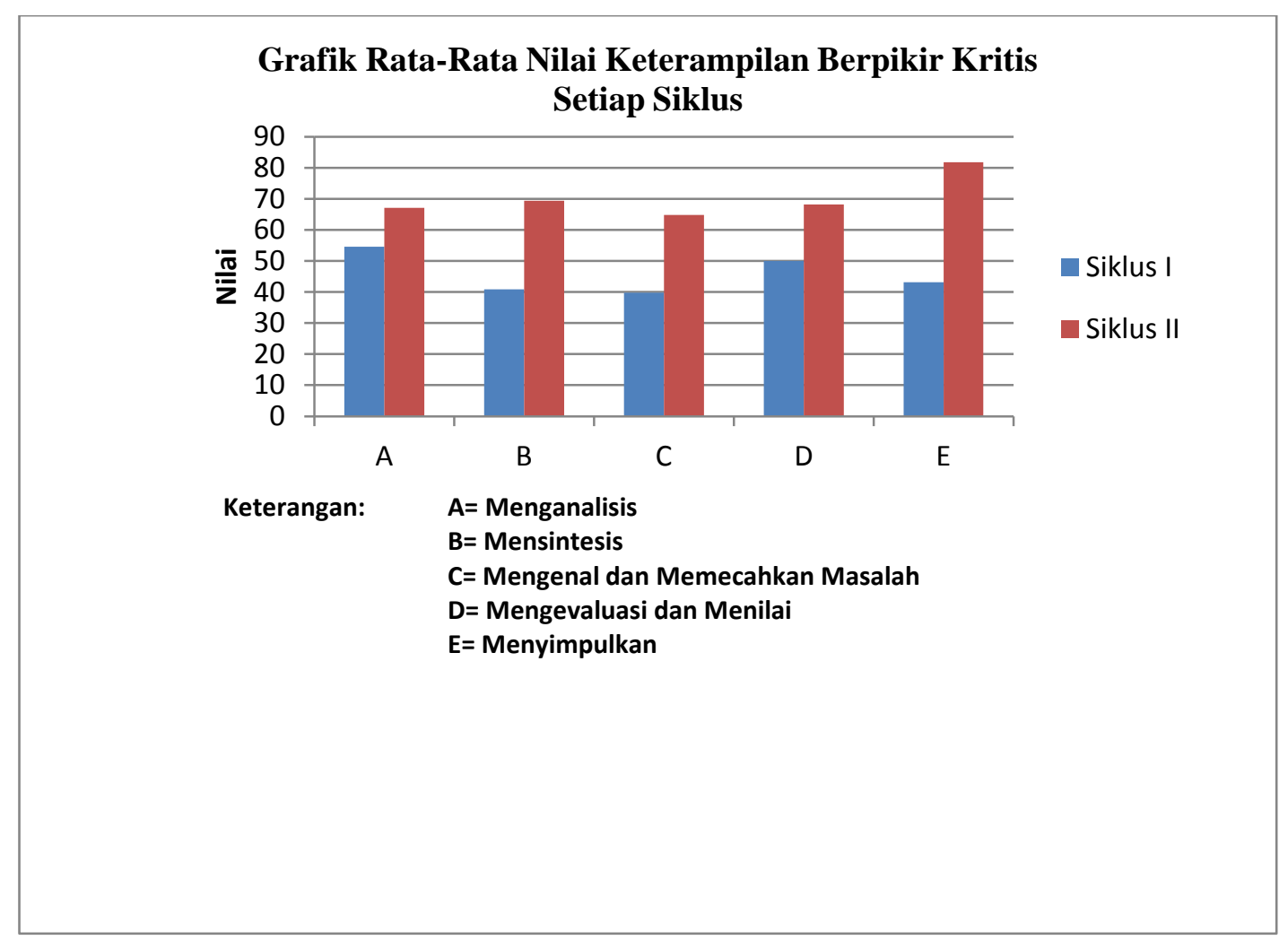

Gambar 1 Grafik Rata-Rata Nilai Keterampilan Berpikir Kritis

b. Grafik Skor Rata-Rata Keterlaksanaan Pembelajaran Setiap Siklus

Berdasarkan Tabel sebelumnya diketahui bahwa terdapat peningkatan keterlaksanaan pembelajaran oleh guru dari siklus I ke siklus II dalam menerapkan model pembelajaran inkuiri terbimbing di kelas VIII $_{\text {E }}$ SMP Negeri 4 Buton Tengah materi pokok cahaya dan alat optik dari siklus I ke siklus II. Secara jelas perbandingan skor rata-rata keterlaksanaan pembelajaran oleh guru pada siklus I dan Siklus II disajikan pada Gambar 2.

\section{Grafik Skor Rata-Rata Keterlaksanaan Pembelajaran Setiap Siklus}

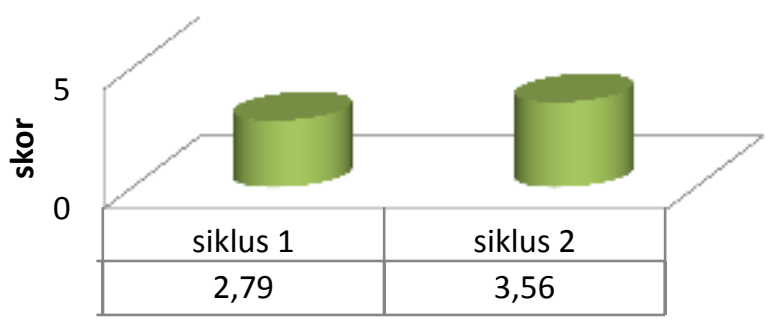

Gambar 2 Grafik Skor Rata-Rata Keterlaksanaan Pembelajaran

c. Grafik Skor Rata-Rata Aktivitas Peserta Didik Setiap Siklus

Berdasarkan Tabel sebelumnya diketahui bahwa terdapat peningkatan aktivitas peserta didik dari siklus I ke siklus II yang diajar dengan model pembelajaran inkuiri terbimbing pada kelas $\mathrm{VIII}_{\mathrm{E}}$ SMP Negeri 4 Buton Tengah materi pokok cahaya dan alat optik. Secara jelas perbandingan skor ratarata aktivitas peserta didik pada siklus I dan Siklus II disajikan pada Gambar 3. 


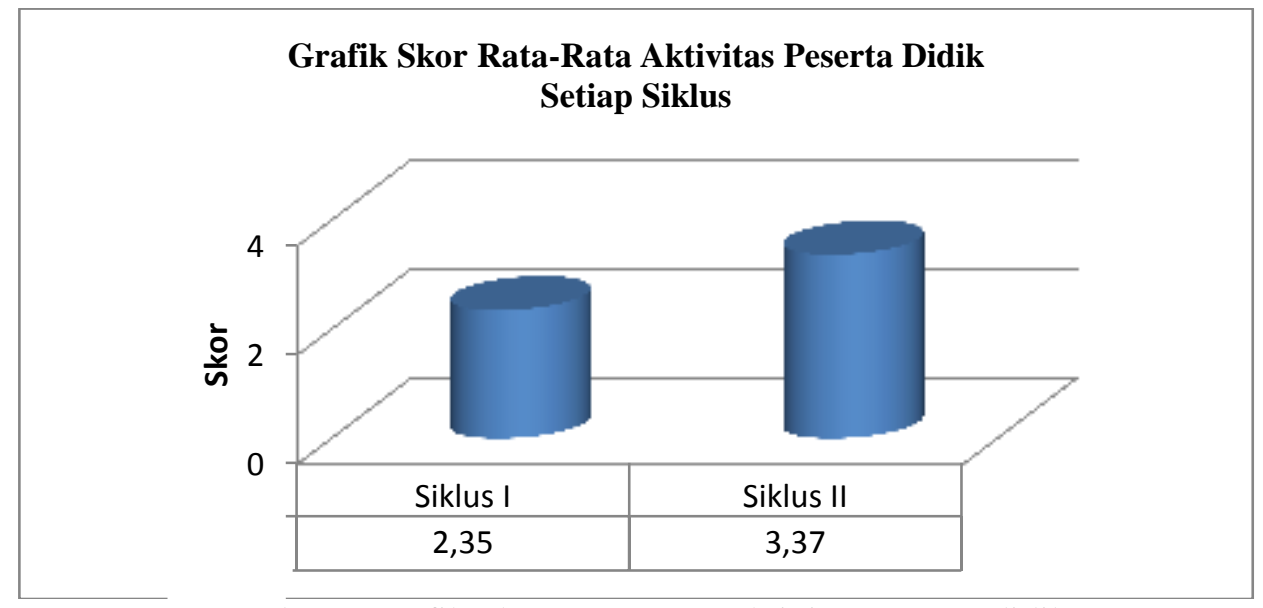

Gambar 3 Grafik Skor Rata-Rata Aktivitas Peserta didik

\section{PEMBAHASAN}

Pelaksanaan penelitian tindakan kelas (PTK) dengan menggunakan model pembelajaran inkuiri terbimbing terdiri dari 2 siklus dengan masingmasing siklus terdiri dari 2 kali pertemuan. Subjek dalam penelitian ini adalah peserta didik kelas VIII $_{\mathrm{E}}$ SMP Negeri 4 Buton Tengah yang berjumlah 22 peserta didik yang terdiri dari 13 peserta didik lakilaki dan 9 peserta didik perempuan. Pada pelaksanaan pembelajaran tiap pertemuannya terdapat kegiatan yang mencerminkan ciri khas dari model pembelajaran inkuiri terbimbing antara lain, di awal proses pembelajaran guru membuka pelajaran dan memeriksa kesiapan peserta didik, memberikan apersepsi, menyampaikan tujuan pembelajaran, guru membagi peserta didik dalam beberapa kelompok yang beranggotakan 5-6 orang peserta didik setiap kelompok, guru menyajikan masalah berupa gambar yang ditampilkan pada LKPD agar peserta didik dapat merumuskan masalah dan merumuskan hipotesis. Setelah itu guru mengarahkan peserta didik untuk mendapatkan informasi dengan melakukan percobaan yang kemudian hasil percobaannya diolah, setelah itu guru mengarahkan peserta didik untuk mengecek benar dan tidaknya hipotesis yang telah dirumuskan berdasarkan hasil percobaan, lalu membuat kesimpulan.

\section{Siklus I}

Siklus I dilaksanakan sesuai rencana yaitu dua kali pertemuan pada tanggal 04 dan 06 April 2019. Pada pertemuan pertama yang dipelajari adalah sub materi sifat-sifat cahaya dan pertemuan kedua yang dipelajari adalah sub materi cermin.

Keterampilan Berpikir Kritis

Penggunaan model pembelajaran inkuiri terbimbing pada masing-masing fase memiliki peran penting dalam melatih keterampilan berpikir kritis peserta didik.Berdasarkan analisis data deskriptif terhadap hasil tes keterampilan berpikir kritis peserta didik pada siklus I dengan sub materi sifat-sifat cahaya dan cermin, dapat diketahui bahwa peserta didik mengalami kesulitan dalam hal keterampilan menganalisis, mensintesis, mengenal dan memecahkan masalah, menilai dan mengevaluasi serta menyimpulkan. Keterampilan berpikir kritis peserta didik pada indikator menganalisis tergolong dalam kategori rendah dengan nilai 54,55, sedangkan untuk indikator mensintesis, mengenal dan memecahkan masalah dan menyimpulkan tergolong dalam kategori sangat rendah dengan nilai rata-rata 40,91, 39,77 dan 43, 18 serta untuk indikator mengevaluasi dan menilai termasuk dalam kategori rendah dengan nilai 50,00. Keterampilan berpikir kritis yang rendah menunjukkan hasil belajar yang rendah pula. Hal ini terbukti dari hasil belajar peserta didik, dari total 22 orang peserta didik, yang mampu mencapai nilai KKM hanya sebanyak 4 orang peserta didik dengan presentase ketuntasan secara klasikal hanya sebesar 18,19\%.

Rendahnya keterampilan berpikir kritis peserta didik ini karena peserta didik belum paham tentang indikator-indikator keterampilan berpikir kritis dengan baik dan belum terbiasa dengan model soal berpikir kritis yang mencangkup indikator menganalis, mensintesis, mengenal dan memecahkan masalah, mengevaluasi dan menilai serta menyimpulkan. Kemampuan berpikir kritis peserta didik selama proses pembelajaran pada siklus I juga dikatakan belum optimal yang dibuktikan dengan aktivitas siswa dalam melakukan pengamatan, mengajukan pertanyaan, merumuskan hipotesis, melakukan percobaan, berdiskusi dan menganalisis hasil percobaan hanya berada pada 
kategori cukup, terlebih dalam aktivitas membuat kesimpulan peserta didik masih berada pada kategori kurang.

Rendahnya keterampilan berpikir kritis dan aktivitas peserta didik ini tidak terlepas dari keterlaksanaan pembelajaran yang pada beberapa aspeknya masih berada pada kategori cukup. Aspekaspek tersebut berdampak pada kesiapan peserta didik dalam belajar masih sangat rendah karena dalam membuka pelajaran guru tidak memperhatikan kesiapan peserta didik secara baik, peserta didik hanya sekedar mendengarkan tanpa mengingat dan memahami tujuan pembelajaran yang akan dicapai karena guru hanya membacakan tujuan pembelajaran yang akan dicapai dalam pembelajaran, peserta didik belum mampu untuk merumuskan hipotesis dan menganalisis data berupa kesimpulan dengan baik disebabkan guru hanya terfokus melakukan bimbingan oleh satu kelompok saja, terdapat banyak peserta didik yang masih merasa bingung dan belum mengerti tentang materi yang diajarkan karena guru tidak melakukan review sehingga peserta didik tidak berani untuk bertanya dan mengungkapkan pendapatnya, peserta didik tidak fokus tentang materi apa yang harus dipelajari terlebih dahulu sebagai bekal awal pembelajan karena guru tidak menginformasikan materi untuk pertemuan selanjutnya dan banyak peserta didik yang gelisah dalam ruangan karena waktu pembelajaran telah melebihi waktu yang ditentukan, ini disebabkan guru masih kurang cermat dan tegas dalam mengelola pembelajaran sesuai dengan apa yang telah di rencanakan.

Gambaran keterlaksanaan pembelajaran dengan model pembelajaran inkuiri terbimbing dalam meningkatkan keterampilan berpikir kritis peserta didik pada siklus I menunjukkan bahwa masih terdapat kelemahan pada beberapa fase model inkuiri terbimbing dalam meningkatkan keterampilan berpikir kritis kelas VIII $_{\mathrm{E}}$ SMP Negeri 4 Buton Tengah. Kelemahan pada beberapa fase model inkuiri tebimbing tersebut dalam meningkatkan keterampilan berpikir kritis peserta didik disebabkan karena peserta didik belum terbiasa dengan model yang diterapkan oleh guru dan dan peserta didik belum paham tentang indikatorindikator keterampilan berpikir kritis dengan baik, serta peserta didik tidak terbiasa dalam mengerjakan soal-soal berpikir kritis.

Berdasarkan temuan tersebut, maka aspek-aspek yang perlu diperbaiki pada siklus II adalah sebagai berikut: 1) Guru lebih baik lagi dalam memeriksa kesiapan peserta didik dengan menannyakan tentang tugas-tugas yang telah diberikan pada pertemuan sebelumnya untuk mengetahui sejauh mana tingkat pemahaman peserta didik. 2) Guru menyampaikan tujuan pembelajaran secara lebih mendetail dengan cara menuliskan tujuan pemebelajaran dipapan tulis agar dapat ditulis dan mampu diingat oleh peserta didik. 3) Guru lebih memberikan bimbingan kepada peserta didik untuk merumuskan hipotesis dengan menjelaskan maksud dari hipotesis itu sendiri dan memberikan contoh dalam membuat hipotesis serta melakukan bimbingan terhadap masing-masing kelompok. 4) Guru memberikan bimbingan yang lebih dengan tidak hanya terpaku pada satu kelompok melainkan harus sama untuk setiap kelompok yang ada dalam mengarahkan peserta didik untuk menganalisis data percobaan berupa kesimpulan. 5) Guru harus meriview kembali kegiatan hasil pemebelajaran agar materi atau poinpoin yang belum dipahami siswa dapat dijelaskan secara baik dan dapat dilakukan tanya jawab tentang apa yang belum dipahami oleh siswa sehingga terjadi interaksi yang baik antara guru dan peserta didik. 6) Guru menginformasikan materi untuk pertemuan selanjutnya secara lebih mendetail dengan memberikan tugas-tugas yang akan ditanyakan sebelum memulai pembelajaran pada pertemuan selanjutnya tersebut. 7) Guru mengalokasikan waktu sesuai dengan yang tertuang pada RPP, dengan membatasi tiap tahap yang dikerjakan oleh siswa secara lebih rinci.

\section{Siklus II}

Gambaran keterlaksanaan pembelajaran dengan model inkuiri terbimbing dalam meningkatkan keterampilan berpikir kritis peserta didik pada siklus II menunjukkan bahwa fase-fase model inkuiri terbimbing yang memiliki peran dalam melatih keterampilan berpikir kritis peserta didik telah berfungsi sebagaimana mestinya, sehingga keterampilan berpikir kritis peserta didik kelas $\mathrm{VIII}_{\mathrm{E}}$ SMP Negeri 4 Buton Tengah telah mengalami peningkatan dari siklus I. Berdasarkan analisis deskriptif masing-masing indikator keterampilan berpikir kritis pada siklus II terlihat bahwa rata-rata keterampilan berpikir kritis untuk indikator menganalisis meningkat dari 54,55 menjadi 67,05 dengan kategori sedang. Indikator mensintesis meningkat dari 40,91 menjadi 69,32 dengan kategori sedang. Indikator mengenal dan memecahkan masalah meningkat dari 39,77 menjadi 64,77 dengan kategori sedang. Indikator mengevaluasi dan menilai meningkat dari 50,00 menjadi 68,18 dengan kategori sedang. Serta indikator menyimpulkan 
meningkat dari 43,18 menjadi 81,82 dengan kategori sangat tinggi. Peningkatan keterampilan berpikir kritis peserta didik ini juga menunjukkan bahwa hasil belajar peserta didik pada siklus II juga mengalami peningkatan, dimana dari total 22 orang peserta didik, sebanyak 17 orang peserta didik telah memenuhi KKM dengan presentase ketuntasan secara klasikal mencapai 77,28 \%. Dengan ini, maka dapat diketahui bahwa tingginya keterampilan berpikir kritis peserta didik, menunjukkan hasil belajar peserta didik yang tinggi pula (Jayanti dan Bunga, 2018). Hasil yang diperoleh ini juga didukung dengan meningkatnya aktivitas peserta didik di siklus II yang berada pada kategori baik.

Peningkatan yang terjadi menunjukkan bahwa guru telah melakukan perbaikan berdasarkan analisis dan refleksi yang telah dilakukan sebelumnya pada siklus I. Peningkatan yang terjadi juga tidak terlepas dari peran peserta didik dalam mengikuti proses pembelajaran dengan model inkuiri terbimbing. Peningkatan keterampilan berpikir kritis peserta didik membuktikan bahwa model pembelajaran inkuiri terbimbing memberikan kesempatan bagi peserta didik untuk belajar aktif dalam merumuskan masalah, menganalisis, mengambil kesimpulan dan keterampilan lain yang dapat memberikan nilai positif dari segi keterampilan berpikir kritis peserta didik (Chodijah, Fauzi dan Wulan, 2012). Berdasarkan uraian tersebut, dapat dibuktikan bahwa model inkuiri terbimbing dapat meningkatkan keterampilan berpikir kritis peserta didik kelas VIII $_{\mathrm{E}}$ SMP Negeri 4 Buton Tengah pada materi cahaya dan alat optik.

\section{KESIMPULAN}

Kesimpulan pada penelitian ini yaitu "keterampilan berpikir kritis peserta didik kelas VIII $_{\mathrm{E}}$ SMP Negeri 4 Buton Tengah melalui penerapan model inkuiri terbimbing mengalami peningkatan. Dimana pada siklus I rata-rata keterampilan berpikir kritis peserta didik sebesar 45,68 yang berada pada kategori rendah. Setelah dilaksanakan tindakan pada siklus II diperoleh nilai rata-rata sebesar 70,23 yang berada pada kategori sedang".

\section{DAFTAR PUSTAKA}

Anitah, Sri. 2009. Media Pembelajaran. Surakarta: Surakarta : Panitia Sertifikasi Guru Rayon 13 FKIP UNS.
Arikunto S, 2006. Prosedur Penelitian Suatu Pendekatan Praktik, Ed Revisi VI. Jakarta : Penerbit PT Rineka Cipta.

Aunurrahman. 2009. Belajar dan Pembelajaran. Bandung: Alfabeta.

Daryanto. 2001. Evaluasi Pendidikan. Jakarta: Rineka Cipta.

Depdikbud. 2000. Kamus Besar Bahasa Indonesia. Jakarta: Balai Pustaka.

Eggen, Paul \& DonKauchak. 2012. Strategi dan Model Pembelajaran. PT Indeks.Jakarta.

Jakfar. 2016. Profil Pemahaman Siswa Berdasarkan Tingkat Kemampuan Matematik. Disertasi: Unoversitas Negeri Surabaya.

Jauhar,M. 2011. Implementasi PAIKEM dari Behavioristik sampai Konstruktivistik sebuah Pengembangan Pembelajaran Berbasis (CTL).Jakarta: Prestasi Pustaka Publisher.

Joice and Well, M. 1996. Model Of Teaching Fifth Edition.USA: A Simon and Schaster Company.

Karli, H dan Margareta Sri Yuliaritiningsih., 2011. Implementasi Kurikulum Berbasi Kompetensi: Model-Model Pembelajaran Jilid 2. Bandung: BinaMedia Informasi.

Kholifudin, M. Yasin. 2012. Pembelajaran Fisika dengan Inkuiri Terbimbing Melalui Metode Eksperimen dan Demonstrasi Ditinjau dari Gaya Belajar Siswa. Yogyakarta: Universitas Negeri Yogyakarta.

Krulik, S. \& Rudnick. 1999. Innovate Task to Improve Critical and Creative Thingking Skill. Developing Mathematica. Reasoning in Grades K-12, pp.138-145.

Muijs, D. \& Reynolds. 2008. Effective Teaching Teori dan Aplikasi. Yogyakarta: Pustaka Pelajar.

Mulyasa, E. 2007. Kurikulum Berbasis Kompetensi, Konsep, Karakteristik, dan Implementasi. Bandung: Remaja Rosdakarya. 
National Research Cout 2000. Cil, Inquiry and the National Science Education Standards: A Guided For Teaching and Learning. Washington DC:National Academy Press.

Neni, Z. 2006. Psikologi Pengantar Pemahaman Diri dan Lingkungan. Jakarta: Kizi Brothers.

Putra, Sitiatava R. 2012. Desain Belajar Mengajar Kreatif Berbasis SAINS. Jojgakarta: DIVA Press.

Rosyada, D. 2004. Paradigma Pendidikan Demokratis. Jakarta: Prenada Media.

Slameto. 2002. Belajar dan Faktor-faktor yang Mempengaruhinya. Jakarta: Rineka Cipta.

Sudjana, N. 1996.Metoda Statistika (Edisi Revisi). Bandung: Tarsito.

Sudjana (2005). Penilaian Hasil Proses Belajar Mengajar. Bandung: PT Remaja Rosdakarya.

Sumaji, et. al. 1997. Pendidikan Sains yang Humanis. Yogyakarta: Kanisius.

Suryosubroto. 2009. Proses Belajar Mengajar Di Sekolah. Jakarta. Rineka cipta.

Trianto, 2007. Model Pembelajaran Terpadu, Konsep, Strategi dan Implementasi dalam Kurikulum Tingkat Satuan Pendidikan (KTSP).akarta: PT. BumiAksara.

2011. Mendesain Model Pembelajaran Inovatif Kontemporer. Penerbit Bumi Aksara. Jakarta.

Trowbridge, L. W. \& R. W. Bybee. 1990. Becoming a Secondary Scholl Science Teacher. Melbourne: Merill Publishing Company.

Usman, M, U. Setiawati, L. 1993. Upaya Optimalisasi Kegiatan Belajar Mengajar. (Bahan Kajian PKG, MGBS, MGMP). Bandung: PT. Remaja Rosdakarya.
Zubaedi 2012. Desain Pendidikan Karakter: Konsepsi dan Aplikasi dalamLembaga Pendidikan. Kencana. Jakarta.

Cahyono, D. 2013. Penerapan Model Model Pembelajaran Children Learning in Sciense (CLIS) untuk Meningkatkan Kemampuan Berpikir Kritis dan Hasil Belajar Fisika Siswa Kelas X-7 SMA Negeri 1 Turen. Malang: Universitas Negeri Malang.

Kurniawati, I. D, Wartono. Diantoro. 2014. Pengaruh Pembelajaran Inkuiri Terbimbing Integrasi Peer Instruction Terhadap Penguasaan Konsep dan Kemampuan Berpikir Kritis Siswa. Jurnal Pendidikan Fisika Indonesia. 10(1): 36-46.

Priono, A. Mulyanto, B. Nurhayati. 2015. Penerapan Model Pembelajaran Inkuiri Terbimbing untuk Meningkatkan Kemampuan Berpikir Kritis Siswa Kelas XI SMA Negeri 3 Lubuklinggau Tahun Pelajaran 2014/2015. Lubuklinggau: STIKIP-PGRI.

Riyadi, U. 2008. Model Pembelajaran inkuiri dengan Kegiatan Laboratorium untuk Meningkatkan Ketera,pilan Berpikir Kritis Siswa Pokok Bahasan Fluida Statis. Semarang: UNS.

Chodijah, S. Fauzi, A. dan Wulan, R. 2012. Pengembangan Perangkat Pembelajran Fisika Menggunakan Model Guided Inquiry yang Dilengkapi Penilaian Portofolio pada Materi Gerak Melingkar. Jurnal Penelitian Pembelajran Fisika. Vol. 1. ISSN: 2252-3014. Padang: Universitas Negeri Padang.

Holmes. Vicky-Lyn. 2011. Standardizing the Inquiry Lesson: Improving the Caliber of Science Inquiry . E. J. Literacy Throught Science. Vol. 10.

Jayanti, A \& Bunga, D. A. 2018. Pengaruh Pembelajaran Inkuiri Terbimbing Terhadap Keterampilan Berpikir Kritis Peserta Didik Kelas XI MIA SMA Negeri 2 Barru. Jurnal Sains dan Pendidikan Fisika. Jilid 14. No 1. Makassar: Universitas Negeri Makassar. 
Murti, B. 2009. Peningkatan Kemampuan Berpikir Kritis Dalam Pembelajaran IPA Melalui Model Problem Based Learning (PBL) Pada Peserta Didik Kelas VIII SMP Negeri 1 Turi . E-journal pendidikan IPA 1 (1) (htttp://journal.student.uny.ac.id)

Musdar. Hasan, M. Halim, A. 2015. Efektivitas Penggunaan Model Inkuiri Terbimbing dengan Kegiatan Laboratorium Virtual Materi Vluida Statis untuk Meningkatkan Pemhaman Konsep dan Keterampilan Berpikir Kritis Siswa. Jurnal Penelitian Sains Indonesia. 3. 114-112.

Normaya, Karim. 2015. Kemampuan Berpikir Kritis Siswa dalam Pembelajaran Matematika dengan Menggunakan Model Jucama di Sekolah Menengah Pertama.Jurnal Pendidikan Matematika. Vol. 3 No. 1.
Banjarmasin: Universitas Lambung Mangkurat.

Noviana, S. Connie dan Hamdani, D. 2017. Penerapan Model Inkuiri Terbimbing untuk Meningkatkan Aktivitas, Hasil Belajar dan Keterampilan Berpikir Kritis Siswa Kelas X IPA.3 SMA Negeri 3 Bengkulu Tengah. Jurnal Pembelajaran Fisika. Vol. 1. No. 1. Bengkulu: Universitas Bengkulu.

Achmad, Arief. 2007. Memahami Berpikir Kritis. [online]. Tersedia: http://researchengines. com/1007arief3.html.

Paul, R. \& L. Elder. 2007. The Miniature Guide to Critical Thingking Concepts and Tools. www.criticalthinking.org. 